\title{
OPPLAERING GA BEDRE BRUK AV PLEIEPLAN
}

\section{Dokumentasjon. De ansatte ble tryggere på egne} observasjoner og brukte elektronisk pleieplan mer.
DOKUMENTASJONSPROSJEKT:

Artikkelen bygger på

$60 \%$ pralisis $40 \%$ teori

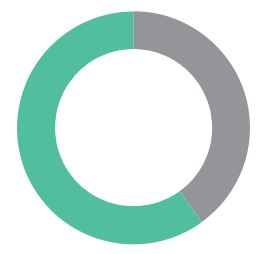

DOI-NUMMER:

10.4220/Sykepleiens.2016.57523

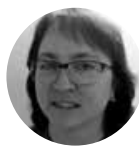

Ellen

Ongkiehong, Avdelingsleder ved avdeling Vefsn kommune.

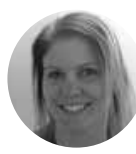

Hege Tangen, Sykepleier ved avdeling Nyrudskogen, Vefsn kommune.

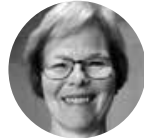

Tone Knudsen Oddvang, Førstelektor, Profesjonshøgskolen, Nord Universitet,

Campus Helgeland.

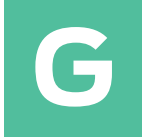

jennom et dokumentasjonsprosjekt ved vår avdeling ønsket vi å ta i bruk pleieplanen i det elektroniske fagsystemet for å få en mer ensartet, kontinuerlig og fullstendig dokumentasjon av sykepleien til pasientene.

HOLDNINGSENDRING. Å la alle medarbeiderne i avdelingen lære det samme, hadde god effekt på bruken av dokumentasjon i avdelingen. Det medvirket til flere gode faglige diskusjoner, og hver enkelt så hvor oversiktlig dokumentasjonen ble. I etterkant har vi sett en holdningsendring. Fra: «Jeg trenger ikke dokumentere hver dag», dokumenterer vi nå litt uansett, fordi det skjer noe med pasienten hver dag. Det å dokumentere ble ufarliggjort, og hver enkelt ble tryggere på dette. Alle fikk samme verktøy og kunnskap til å utføre dokumentasjonen. Erfaring viser at man må bruke tid på prosessen og ikke gi opp. Holdninger og vaner endres ikke over natta.

LEDERANSVAR. Avdelingsleder har det sykepleiefaglige ansvaret for avdelingen, og dette innebærer ansvar for at nødvendige tjenester leveres med forventet kvalitet. Hun må sørge for at avdelingen er faglig oppdatert samt arbeide med arbeidsmiljøet. Dette krever at en avdeling hele tiden er dynamisk og i endring.
For at man skal kunne oppnå en god endring i en avdeling i form av både økt kunnskap og holdningsendringer, må leder være til for andre enn seg selv. Gjennom ledelse, som kan ses på som en form for utdanning av andre, vil man kunne føre medarbeiderne fra ett sted til et annet. Utdanning skaper noe som ikke var der fra før og gir økt kunnskap, ferdigheter og innsikt. En klok leder vil være en god lærer og en god lærer vil være en god leder (1).

BAKGRUNN. Dokumentasjonssystemer kan brukes på mange måter. For å gi pasienten best mulig pleie er det viktig at vi dokumenterer systematisk og oversiktlig.

Målet med sykepleiedokumentasjon er at pasientens interesser og rettigheter ivaretas. For å ivareta pasientens sikkerhet må all relevant informasjon være tilgjengelig for den som utfører pleien. Dokumentasjon skal beskrive hvilke vurderinger og tiltak som blir iverksatt, og evalueringen av disse. Da kan man bedømme hvilken virkning og kvalitet pleien man utfører har. Dokumentasjon blir et middel til kvalitetssikring (2).

LOVPÅLAGT. Ifølge helsepersonelloven er vi pliktige til å føre journal for den enkelte pasient (3). I loven er alle som yter helsehjelp definert som helsepersonell, og det er den som yter helsehjelpen som har lovfestet plikt til å dokumentere for hver enkelt pasient. I tillegg må det tydelig framkomme hvem som har gitt og er ansvarlig for helsehjelpen (2)

Sykepleiedokumentasjon er et arbeidsredskap som gir nøyaktighet i en hektisk hverdag. Og når man bruker tiltaks- og pleieplan fremmer man individuell sykepleie. Det dreier seg om faglig ansvar, og man synliggjør faglige vurderinger slik at man kan gi best mulig pleie til den enkelte pasient. Sykepleiedokumentasjon brukes som bindeledd mellom alle som skal hjelpe pasienten (2)

MANGELFULL. I avdelingen hadde vi lenge sett at dokumentasjonen i pasientjournalen var utilfredsstillende og mangelfull og at en del av det som var dokumentert var dokumentert på feil plass i det elektroniske fagsystemet. Sykepleiere erfarte at det var vanskelig å få en god oppfølging og kontinuitet på forordnede behandlinger fra lege, fysioterapeut og andre. Avdelingen er stor, noe som gjør det utfordrende å følge opp hver enkelt pasient. Vi var redde for at viktig informasjon kunne gå tapt på grunn av dårlig eller manglende dokumentasjon.

UNDERVISNING. Avdelingsleder ønsket at medarbeiderne i avdelingen skulle bli tryggere på hva
Fakta $\bullet$

Hoved-

budskap

Manglende dokumentasjon var et problem $\mathrm{i}$ avdelingen. Ved internundervisning og å bygge på erfaringer hos medarbeiderne tilførte vi kunnskap og trygghet i bruk av det elektroniske verktøyet. Kommunikasjon og samarbeid i avdelingen økte. For å få dette til har leders medvirkning vært sentral.

Nøkkelord

Les mer og finn litteraturhenvisninger på våre nettsider

- Sykepleie

- Dokumentasjon

- Pleieplan

- Pasientsikkerhet 


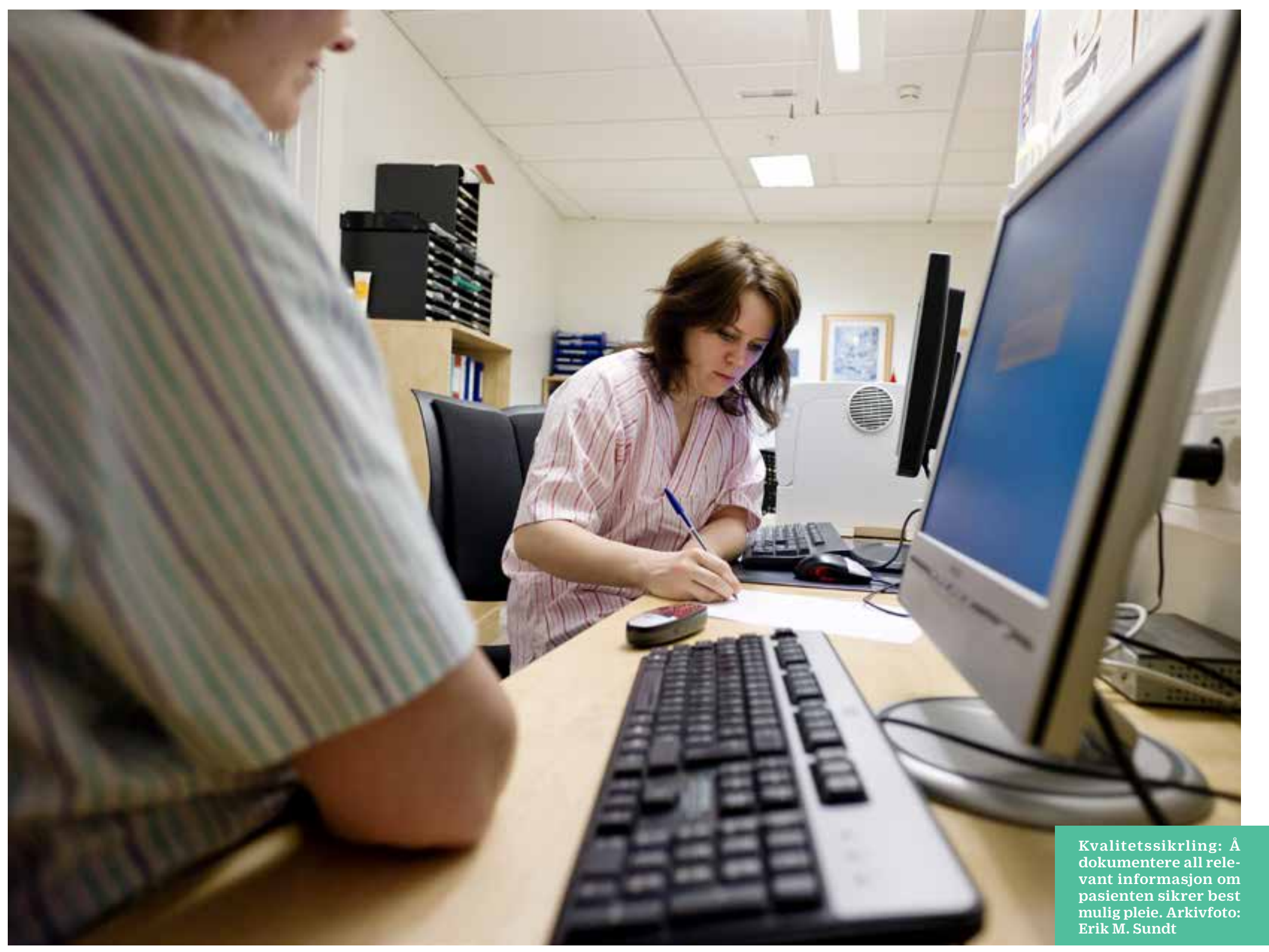

som skulle dokumenteres og bruke det elektroniske dokumentasjonssystemet. Ved bruk av internundervisning ønsket vi å øke medarbeidernes kompetanse på dokumentasjon.

Å drive med internundervisning er en ekstraordinær oppgave som er mer kompleks enn det avdelingen driver med til daglig. Vi valgte derfor å jobbe med dokumentasjonsopplæringen i prosjektsform da dette var en målrettet engangsoppgave som skulle værer tidsbegrenset (4). Målgruppen for dette prosjektet var alle medarbeidere ved avdelingen som bruker det elektroniske fagsystemet.

MÅL. Effektmål for prosjektet: - Bedre kvalitet på dokumentasjonen i pasientjournal

\section{$\equiv$ «Holdninger og vaner endres ikke over natta.»}

- Endrete formuleringer og hva som dokumenteres i journal

- Medarbeiderne føler økt trygghet $\mathrm{i}$ å dokumentere
- Bedre rapporter mellom vaktskiftene

- Kvalitetssikring av oppfølging av pasientbehandling

- Pasient og pårørende opplever god oppfølging

- At lege og andre samarbeidsparter opplever at problematikk er godt dokumentert og at forordnete behandlinger følges godt opp

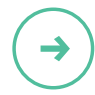


Å overføre kunnskap fra Kardex-skriving til å dokumentere i det elektroniske fagsystemet har for mange medarbeidere vært vanskelig.

DOKUMENTASJON. Sykepleierne har ofte opplevd og får muntlig rapport fra medarbeidere om at pasienten har et problem, for eksempel smerter. Hvilke tiltak som er gjort og effekten dette har hatt, har ikke vært godt nok dokumentert. Flere ganger har sykepleier erfart at det har vært vanskelig å overbevise legen om problemer hos pasientene, da det har manglet dokumentasjon som kunne vise til utprøvde tiltak og effekten av disse.

Vi ønsket at tiltaks- og pleieplan i dokumentasjonssystemet skulle brukes i stedet for å skrive enkle journalnotater. Å bruke tiltaks- og pleieplan gir en mye bedre oversikt og oppfølging i pasientjournal. Man får økt oppmerksomhet på pasientens problem og bedre oppfølging av hvert enkelt tiltak.

Vi ønsket også at tilsynslegen på en enklere måte skulle få en god og oversiktlig dokumentasjon på hva som blir gjort og hvilken effekt behandling og tiltak har. Ved å gjøre legen oppmerksom på hvordan vi dokumenterer i sykepleiejournalen håpet vi å oppnå dette.

SPøRRESKJEMA. For å skreddersy opplæringen ble det i for- og etterkant av prosjektet utført en spørreundersøkelse. Utvalget var strategisk, «Purposeful sampling», (5) og ble sett på som nødvendig for å få tilstrekkelig data. Spørreskjemaet var en blanding av avkrysning og mulighet for egne svar, og ble levert i den enkeltes posthylle på arbeidsplassen. Svarprosenten var på 71 prosent.

Svarene dannet grunnlaget for å designe et tilpasset opplæringstilbud. Ut fra innkomne svar ble målet for kurset: Hvordan skrive og rapportere i tiltaks- og pleieplan, inn- og utmelding av pasienter, e-melding samt noen enkelte registreringstyper som NB-opplysninger, effekt legemidler, gitt informasjon.
KURS. Det ble satt opp følgende kursrekke:

- Kurs 1 «Tiltaks- og pleieplan»

- Kurs 2 «Inn- og utmelding og emelding»

- Kurs 3 «Ulike reg. typer og repetisjon av tiltaks og pleieplan»

I tillegg ble lovverket tilknyttet dokumentasjonsplikten gjennomgått for å forankre forståelsen av den enkeltes plikt til å dokumentere. Kurs 2 var bare for sykepleierne, de andre var for alle. Kursene ble satt opp flere ganger. Totalt ble det gjennomført seks kurs à 1,25 timer.

TILTAK. Underveis i internundervisningen ble det mulig å diskutere ulike problemstillinger og erfaringer. Medarbeiderne ble enige om tiltak for best mulig dokumentasjon $\mathrm{i}$ avdelingen. På forhånd ble det laget et case og opprettet en fiktiv pasient i kursbasen. Kursdeltakerne måtte være aktivt med på å formulere hva man skulle skrive, og hva som er greit og ikke greit å skrive.

TRYGGHET. I internundervisningen var det viktig å ufarliggjøre det å dokumentere og giøre medarbeiderne trygge på at de selv skulle dokumentere. Det å diskutere underveis hva som var lurt å tenke på når man dokumenterer, og formidle at det ikke var så farlig om det ikke ble helt korrekt norsk, ga dem trygghet. Det var viktig å formidle at det viktigste er at man skriver det man har observert.

To måneder etter kursene gjennomførte vi en ny spørreundersøkelse blant medarbeiderne på avdelingen. Her fikk vi inn 18 svar av 28 mulige.

RESULTATER. Resultatet av spørreundersøkelsen etter kurset har vi oppsummert som følgende: Av totalt 28 spørreskjema svarte 17 positivt på at de skriver rapport hver dag, mens tre ikke skriver hver dag. De fleste svarte at de følte seg tryggere på det å dokumentere og hvor de skulle dokumentere. Videre sa de at:

- De har lært mye av kurset, kursene var ok.

- Noen glemmer fort igjen og føler de trenger lengre tid på å bli trygge og bedre.

\section{Gjennomsnittlig registreringer per måned før og etter kurs:}

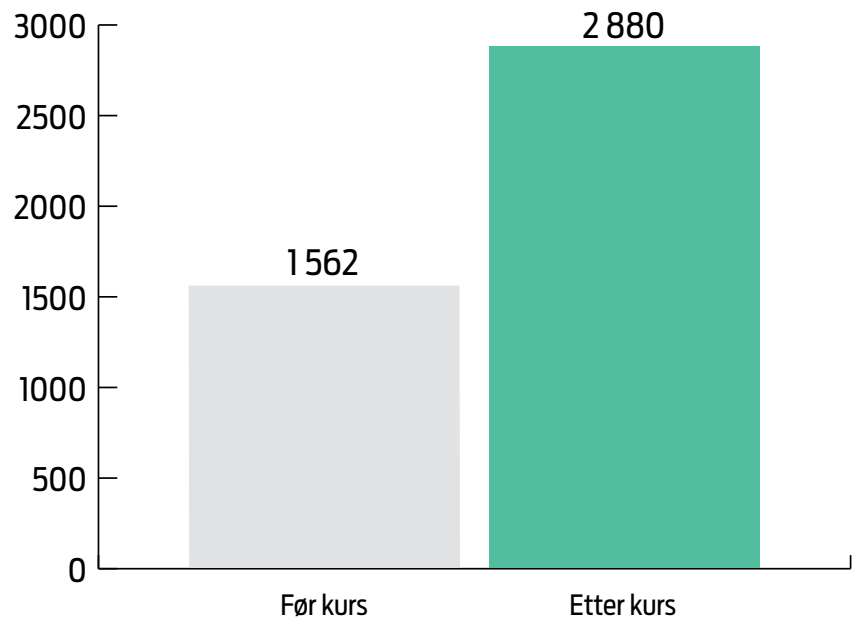

Figur 1. Figuren viser at før avholdte kurs var det registret 1562 registreringer gjennomsnittlig per måned. Etter avholdte kurs var det øket til gjennomsnittlig 2880 pr måned. Dette er en økning på 54 prosent.

- De har fått mer forståelse og vet hvor man går inn i dokumentasjonssystemet.

- Bedre rapport eller rapporten er omtrent som før

- De har fått bedre oversikt i tiltaks- og pleieplan, det er lettere å finne frem.

- De er tryggere på å opprette problemer og er blitt bedre til å skrive rapport.

- Dokumentasjonen er bedre og mer oversiktlig.

- De er blitt flinkere til å spørre etter hjelp hvis de står fast.

- Man trenger lengre tid for å få med alle på å dokumentere hver dag.

I undersøkelsen spurte vi også om medarbeiderne ønsket ytterligere repetisjon og av hva, slik at vi kan repetere enkelte tema på avdelingsmøter eller sette opp nye kurs. Økt dokumentasjon synliggjorde at avdelingen har for få pc-er. Dette gjør at det er en utfordring for medarbeidere å få dokumentert.

SUKSESSFAKTORER. Rammen rundt et prosjekt kan være avgjørende for hvor gode resultater man oppnår. I en avdeling er det avgjørende hvordan leder tilrettelegger, 
motiverer og samarbeider med sine medarbeidere. Vi vil her presentere faktorer vi mener er viktige for å få til en vellykket endring $i$ avdelingen.

Leder må i god tid i forkant informere medarbeiderne om internundervisning og hva man ønsker å oppnå. På den måten øker man forståelsen for at alle må delta og at noen vil måtte gå på kurs på sin fridag, med avspasering som kompensasjon. Er man ute med informasjon i god tid, får den enkelte satt av nødvendig tid til å delta på kurs. Gjennom å informere i god tid kan leder stille krav til medarbeiderne, samtidig som hun kan vise respekt for medarbeidernes behov for å planlegge.

LAV TERSKEL. Alle i avdelingen fikk samme type kursing, og kursene ble holdt av avdelingsleder og en sykepleier i avdelingen. Dette førte til at det var lett å gi hjelp underveis i dagene som fulgte etter kursene. Det ga økt trygghet og førte til mange gode faglige diskusjoner. Vi opplevde ekstra engasjement når tematikken var forankret i eksempler fra avdelingen. For å lykkes er det viktig med lav terskel for å hjelpe hverandre og at man motiverer hverandre til å dokumentere.

NØKKELPERSONER. Det er viktig med nøkkelpersoner i avdelingen som avdelingsleder kan samarbeide med og delegere ansvar til. Avdelingsleder kan ikke bare sette bort jobben, men må finne en balanse mellom delegering, samarbeid og oppfølging. Det gjelder både oppfølging av nøkkelpersonene, men også medarbeiderne generelt $i$ avdelingen. Selv etter endt gjennomføring av opplæringen er det viktig at leder etterspør og følger opp tematikken med jevne mellomrom slik at oppmerksomheten ikke opphører. Her er leders oppgave å la sine medarbeidere ta del i det ansvarsområdet en leder står i, slik at medarbeiderne er villig til å ta et selvstendig ansvar for oppgave- og problemløsning i hverdagen. (1)

FORKLARINGER. I etterkant av kursene ble det laget kortfattede forklaringer på hvordan man dokumenterer i det elektroniske fagsystemet. Forklaringene beskriver hvordan man trinnvis går frem ved dokumentering, og med stikkord for hva og hvordan man kan tenke

\section{«Målet med sykepleie- dokumentasjon er at pasientens interesser og rettigheter ivaretas.»}

og formulere seg innenfor dokumentering i tiltaks- og pleieplanen. Dokumentasjon er et fagområde som det er viktig at en stadig repeterer, etterspør og tilføyer ny kunnskap.

ENGASJEMENT. Opplæring gir grunnlag for utvikling og økt kunnskap. Dette gir engasjement, trygghet og økt lyst til å lære mer. Internundervisning har også god effekt på kommunikasjon og samarbeid i en avdeling, mens ekstern kursing vil kunne bringe inn nye ideer og tanker (6). Det er viktig å sette av tid til dette.

ANERKJENNELSE. Det er svært tilfredsstillende for både leder og medarbeider å se at innsatsen nytter og bærer frukter. Her er det viktig at avdelingsleder tydelig anerkjenner og roser den jobben som utføres. Ros og anerkjennelse stimulerer motivasjon og arbeidslyst (6).

KONKLUSJON. Etter endt prosjekt opplevde vi en markant økning av antall registreringer i pasientens sykepleierjournal i det elektroniske fagsystemet. I dag dokumenteres i større grad i tiltaks- og pleieplan i tråd med sykepleiefagets prinsipper.

Vi har forsøkt rapportering på storskjerm, men dette er ikke tatt i bruk ennå. Likevel har medarbeidere gitt tilbakemelding om at de synes at rapportene i vaktskiftet har blitt bedre.
Avdelingen ønsker å jobbe videre med dette for å styrke rapportsituasjonen ytterligere slik det ble gjort i Rana kommune (7). Dette vil kreve noe praktisk tilrettelegging.

Medarbeiderne forteller at de føler seg tryggere på å dokumentere og forstår det bedre. I tillegg opplever vi at dokumentasjonen er blitt bedre og mer oversiktlig.

OPPSUMMERING. I etterkant ser vi at internundervisning $\mathrm{i}$ egen avdeling gir et eierskap til kurset. Medarbeiderne kjenner kursholderne, og det gjør det enklere å be om hjelp når man lurer på hvordan man skal dokumentere gitte problemstillinger. Vi har opplevd en økning av faglige diskusjoner mellom medarbeidere i forbindelse med dokumenteringen, og at de hjelper hverandre med formuleringer og hvordan man kan dokumentere disse. $\bullet$

\section{REFERANSER:}

1. Brunstad, Paul Otto. Klokt lederskap: mellom dyder og dødssynder. 1. utgave, 1. opplag. Oslo: Gyldendal Norsk Forlag AS, 2009.

2. Heggdal, Kristin. Sykepleiedokumentasjon. Gyldendal Norsk Forlag AS, Oslo 2006. 2. utgave, 3. opplag 2009.

3. Lovdata.no. Lov om helsepersonell m.v. LOV-1999-07-0264. Kapittel 8 .

4. Westerhagen, Harald. m.fl. Prosjektarbeid: Utviklings- og endringskompetanse. 6. utgave, 4. opplag. Oslo: Gyldendal Norsk Forlag AS, 2012.

5. Christoffersen, L., Johannessen, A., Tufte, P.A., og Utne, L. (2015) Forskningsmetode i sykepleierutdanningene, Abstrakt forlag, Oslo.

6. Gotvassli, Kjell-Åge. Bedre personal utvikling. Vannebo Fagpresse A.S. 1991

7. Oddvang, Tone Knudsen. Fra kardex til prosjektor. Sykepleien 8,2013

FAGARTIKLER:

Fagartikler kan sendes til torhild.apall@sykepleien.no 